\title{
Developing a Sustainable Supply Chain Management Practices Framework: A Case Study on the Egyptian Wheat Sector ${ }^{1}$
}

Anton R. Hanna ${ }^{2}$

Dr. Mona M. Abdelghany3

Dr. Sherif Hassan Abdou4

\begin{abstract}
Supply chain practices are activities which integrate both internal relationships within the organization, and external activities with partners, in order to enhance the efficiency and effectiveness of the whole supply chain performance. This research indicated the influence of a number of supply chain practices on performance measures which resulted from conducting a systematic literature review. It is an exploratory research built upon an inductive approach, relying on interviewing a selected number of the organizations involved in the wheat supply chain which are represented in public organizations, and government officials. This research managed to provide two main contributions to the body of knowledge: first, a theoretical framework for sustainable supply chain practices and organizational performance which can be generalized to other disciplines; two, conceptual and applied frameworks for the wheat supply chain in Egypt which can be built upon in the future. The findings led to the conclusion that the wheat supply chain in Egypt is developing to cope with global trends and changes, as well as local needs; however, it is not yet well structured. Its supply chain practices are complex and interrelated, in which each organization has only a certain role. There is a very limited degree of shared vision and goal congruence between organizations in different stages and levels in the supply chain, and
\end{abstract}

${ }^{1}$ Received in 23/8 /2020, accepted in 16/11/2020.

${ }^{2}$ Anton Reda Hanna is currently Reseacher at College of International Transportation and Logestics, Arab Academy for Science, Technology and Maritime Transport (anton.reda91@gmail.com)

${ }^{3}$ Dr. Mona Mohamed Abd El-ghany is currently Associate Professor at Marketing and International Business Department, College of Management and Technology, Arab Academy for Science, Technology and Maritime Transport (monam 2000@ aast.edu)

${ }^{4}$ Dr. Sherif Hassan Abdou is currently Lecturer at College of Management and Technology, Arab Academy for Science, Technology and Maritime Transport (sherifhassan@ aast.edu) 
without shared goals and practices, integration and coordination between involved organizations is impossible.

Keywords: Supply Chain Management - Supply Chain Practices - Sustainability Sustainable Supply Chain

\section{1- Introduction}

Managing contemporary supply chain operations is becoming a more complex and challenging task, that is due to the effects of hyperglobalization and outsourcing; putting all entities in the supply chain and their partners under pressure to keep associated costs to the minimum, while maintaining competitive performance levels (Mentzer et al., 2007).

The management of supply chain operations of strategic commodities such as wheat in the context of this research - is crucial to a country; it also constitutes one of the significant pillars of its stability. Wheat is one of the most important strategic commodities for Egypt, a sector extremely crucial yet underprivileged, its complications have constituted a rich investigation material for researchers in the recent years (Neama, 2016).

Being the main ingredient in the daily bread for over than quarter of the Egyptian population; wheat is counted as a strategic commodity that is directly connected to the country's national security. Its supply chain is a of paramount importance, in which the waste of improper handling and storage processes account for 20\% of Post-Harvest Losses (Ibrahim, 2015); an amount that when considering its importance to the people should be better used than wasted. However, the consecutive Egyptian governments have been pursuing tactics to enhance the performance and decrease the total waste in the past until they came up with the ration card system. Even though, the card system that allows the subsidized baladi bread to reach more than 65 million Egyptians, has worked in the better favor of the people and decreased the waste of the downstream chain (McGill et al., 2015), a room for further enhancement of the chain practices prevails.

Supply chain practices and accompanying logistics activities associated with the storage and transportation of wheat reached to the conclusion that the wheat supply chain and its related logistical activities are at the 
heart of the wheat-waste problem (El-Sakty and Ezzat. 2018). The potentials of further reduction of waste and the upgrading of the overall supply chain of wheat is the main drive for this research.

There is a clear knowledge gap in the area of wheat supply chain practices and performance in Egypt, that is due to the very limited number of researchers who tackled the impact of supply chain practices on overall performance; therefore, this research investigates the actual practices of the wheat supply chain and problems facing the application of sustainable supply chain management practices in Egypt. Aiming to develop a framework linking sustainable supply chain management practices to supply chain performance in the Egyptian wheat sector. It begins with a review of the existing body of literature on supply chain management, and a systematic review of sustainable supply chain management practices, to establish relationship between sustainable practices and organizational performance in the proposed theoretical framework. Then it provides the methodological sequence adopted in order to achieve this aim, followed by the analysis of the case study findings, providing both conceptual and applied framework. And last, it provides a summary of the findings, and recommendations for future research.

\section{2- Literature Review}

Providing a unified and clear definition for supply chain management is not an easy task; due to the massive number of definitions that are being provided and articulated as the field grows and progresses, furthermore, and due to the merge between other disciplines and supply chain, which widens its scope and makes the task of sharing a unified and common definition difficult (LeMay et al., 2017).

Supply chain management is defined as a number of entities that are interconnected with each other in both upstream and downstream flows of products right from the source of material until they reach the point of consumption; accompanied with information sharing across the whole chain; aiming to improving performance on the long-term for both individual entities and all the participants in the supply chain operations (Mentzer et al., 2001). 
Sustainable supply chain management has gained a worldwide attention from business organizations on one hand and governments on the other hand, for the reason that under its scope comes: environmental aspects, health, social, financial, political and resources management ( $\mathrm{Li}$ and Ye, 2014). The attention of researchers to sustainability has grown immensely in the recent years, due to the rising concerns about production conditions; that is the circumstances which products undergo until consumption, and to which degree was that process sustainable (Roy et al., 2018). Therefore, supply chains now are incorporating the concepts of sustainability into their operations. Also, there has been an increasing global trend towards environmental protection, and the reduction of environmental-harming activities caused by organizations while carrying out their daily processes (Varsei et al., 2014).

According to (Gawankar et al., 2017) supply chain management practices are the set of activities that an organization tackle to promote effective and efficient operations, it includes supplier partnership, customer relationship management, information sharing, and information quality. Researchers have developed various combinations of supply chain management practices which change with the industry or the business context of the organization; however, these practices have the same goal of coordinating and integrating supply chain flows internally and across outside partners to maximize the overall performance (Kumar and Kushwaha, 2018).

In order to reach a combination of practices, a systematic literature review was conducted using the database and online resources of the Egyptian Knowledge Bank which are ProQuest, Emerald Insight, and Elsevier Scopus, through utilizing the following keywords: sustainable supply chain management practices, supply chain management performance measures. Relevant results were then filtered according to the following steps: (1) the elimination of title duplications and reading papers' titles, (2) reading the abstract, (3) reading introduction, findings, and conclusion, (4) reading the whole article, and arranging results chronographically. The following table provides the final results of the filtration process chronologically. 
Table 1: Systematic Literature Review Results

\begin{tabular}{|l|l|r|l|}
\hline$\#$ & \multicolumn{1}{|c|}{ Authors } & $\#$ & \multicolumn{1}{|c|}{ Authors } \\
\hline 1 & (Jabbour et al., 2011) & 11 & (Gawankar et al., 2017) \\
\hline 2 & (Talib et al., 2011) & 12 & (Gandhi et al., 2017) \\
\hline 3 & (Green et al., 2012) & 13 & (Truong et al., 2017) \\
\hline 4 & (Gawankar et al., 2013) & 14 & (Gorane and Kant, 2017) \\
\hline 5 & (Laosirihongthong et al., 2013) & 15 & (Al-Shboul et al., 2017) \\
\hline 6 & (Karimi and Rafiee, 2014) & 16 & (AL-Shboul et al., 2018) \\
\hline 7 & (Okongwu et al., 2015) & 17 & (Kumar and Kushwaha, 2018) \\
\hline 8 & (Younis et al., 2016) & 18 & (Wang and Dai, 2018) \\
\hline 9 & (Sundram et al., 2016) & 19 & (Yildiz Çankaya and Sezen, 2019) \\
\hline 10 & (W.A.D.S., 2013) & 20 & (Duong et al., 2019) \\
\hline
\end{tabular}

Source: Developed by the researcher.

The obtained results from the systematic literature review portray a wide array of practices, however, to say that these are all the practices used is not precise, because there is no certain method or pattern in the existing literature to identify supply chain management practices or present a comprehensive list of these practices used by organizations as assumed in (AL-Shboul et al., 2018). Figure 1 provides the attained theoretical framework linking sustainable supply chain management practices to organizational performance.

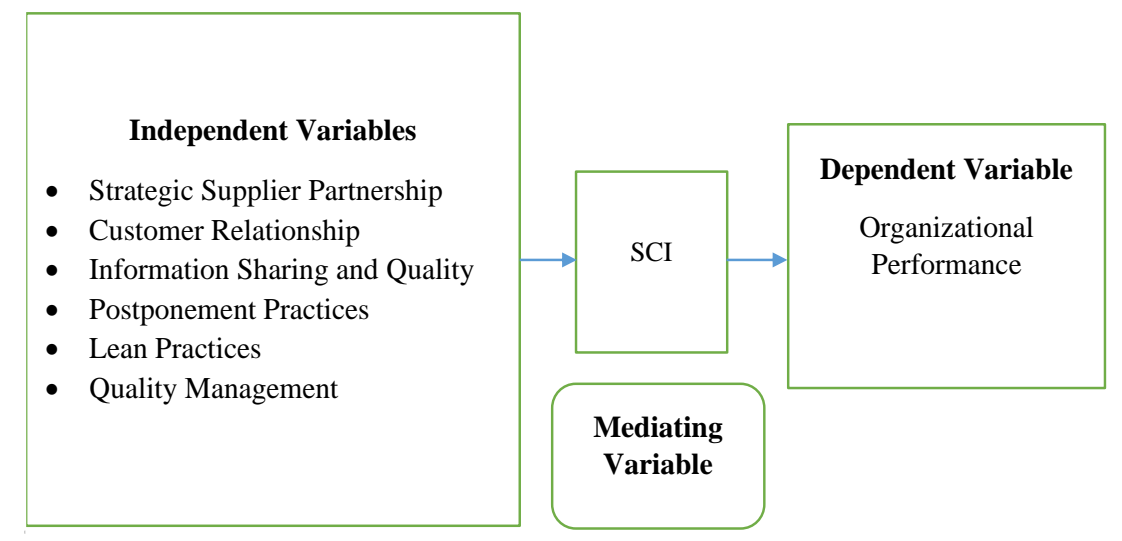

Figure 1: Sustainable Supply chain management practices Theoretical Framework.

Source: Developed by the researcher. 


\section{3- Research Methodology}

The aim of this research is to develop a framework linking sustainable supply chain management practices to supply chain performance in the Egyptian wheat sector. It is an exploratory case study following a set of guidelines to investigate the possibilities for enhancing the actual processes carried out in the wheat sector, while considering the degree to which the application of these practices will improve the performance of the wheat supply chain in Egypt. The research undertakes a thorough review of available contemporary literature and tries to explore how the application of sustainable supply chain management practices will improve and enhance the entire supply chain performance and increase environmental sustainability of wheat in Egypt.

Figure 2 provides the structure of the research stages, the developed theoretical framework will be compared against the current situation in terms of applied practices and actual performance, then a conceptual model will be formulated after having conducted a series of semistructured interviews, then focus groups will provide the applied framework in Egypt. Lastly, the final stage will be the proposition of solutions and recommendation to the current supply chain that should help improving the wheat supply chain current situation.

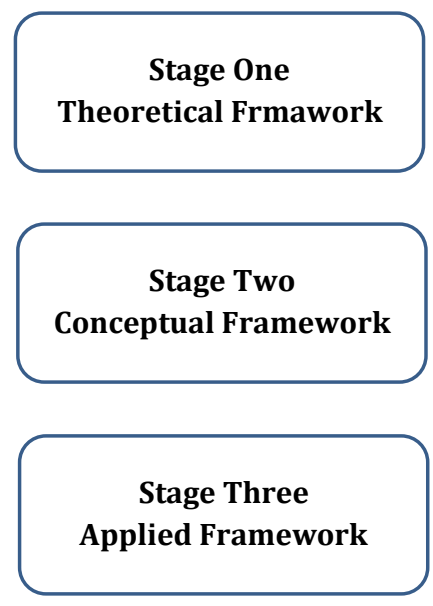

Through conducting a systematic literature review on the relationship between sustianable supply chain managment practices and organizational performance

Through analyzing semi-structured interviews and comparing the results to the theoretical framework.

Through conducting focus groups to validate the findings of the interviews and propose the actual framework for the Egyptian wheat supply chain

Figure 2: Research Stages.

Source: Developed by the researcher 


\section{4-Findings and Discussions}

This paper section is twofold; one is to provide an assessment of the actual practices of the wheat supply chain in Egypt, through conducting a total of 30 semi-structure interviews with key persons in the main entities of the wheat supply chain; in order to reach an adapted conceptual framework. Two, is to identify the applied practices through conducting focus groups aiming at validating the results of the interviews and provide the applied framework.

Semi-structured interviews' questions were formulated to grasp information on the actual practices of the wheat supply chain in Egypt in comparison with the theoretical framework acquired form reviewing literature on sustainable supply chain practices. Published country reports also aided in the formulation of these questions as well. Questions designed as open-ended to give freedom of response to interviewees, and provide space for undiscovered premises in the topic. Participants in the interviews were government officials and experts from: The Ministry of Supply and Internal Trade, the General Authority for Supply Commodities, the Egyptian Holding Company for Silos and Storage, the General Company for Silos and Storage, the Food Industries Holding Company.

\section{4-1 The Proposed Conceptual Framework}

Based on the results of the conducted semi-structured interviews, the following proposed conceptual framework establishes direct, positive relationships between supply chain management practices and organizational performance. After having conducted the analysis, a number of practices were found to be insignificant and irrelevant to the Egyptian wheat supply chain, or have a very degree of applicability, figure 3 provided the adapted framework according to the findings of this stage. 


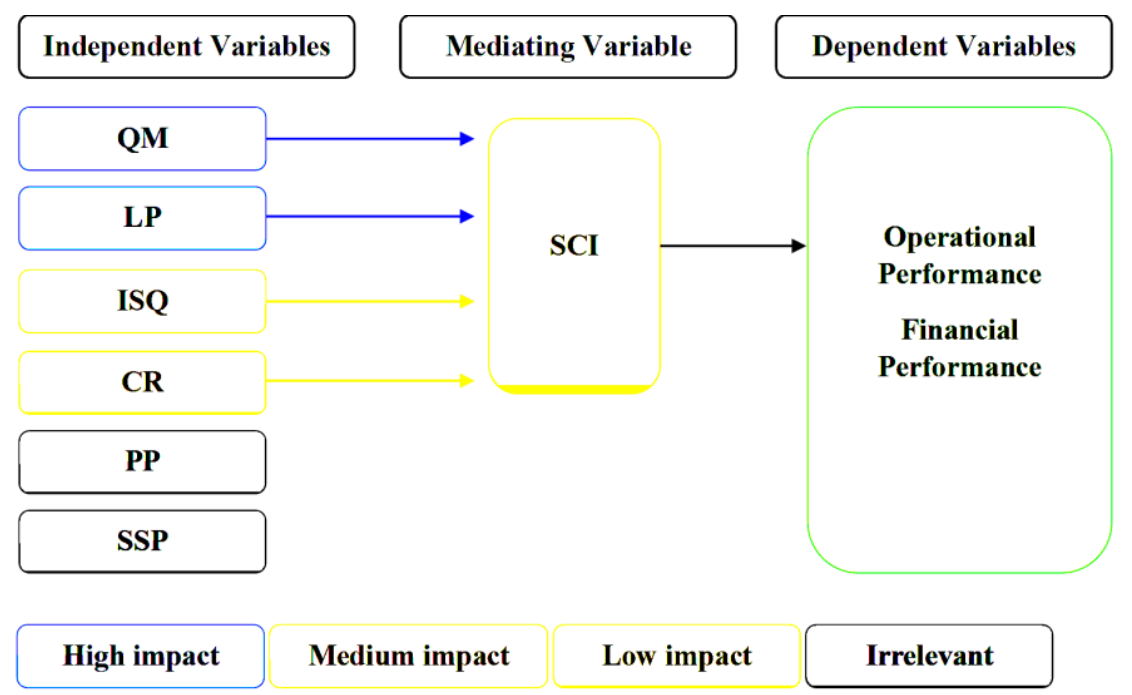

Figure 3: Conceptual Framework.

Source: Developed by the researcher

\section{4-2 Framework Verification}

The following section provides a summary on the three key phases in the wheat supply chain, providing a description for the actual practices carried out and their impact on a certain supply chain performance measures; this step came as a result of validating the findings of the previous steps, figure 4 provides the applied framework after validation.

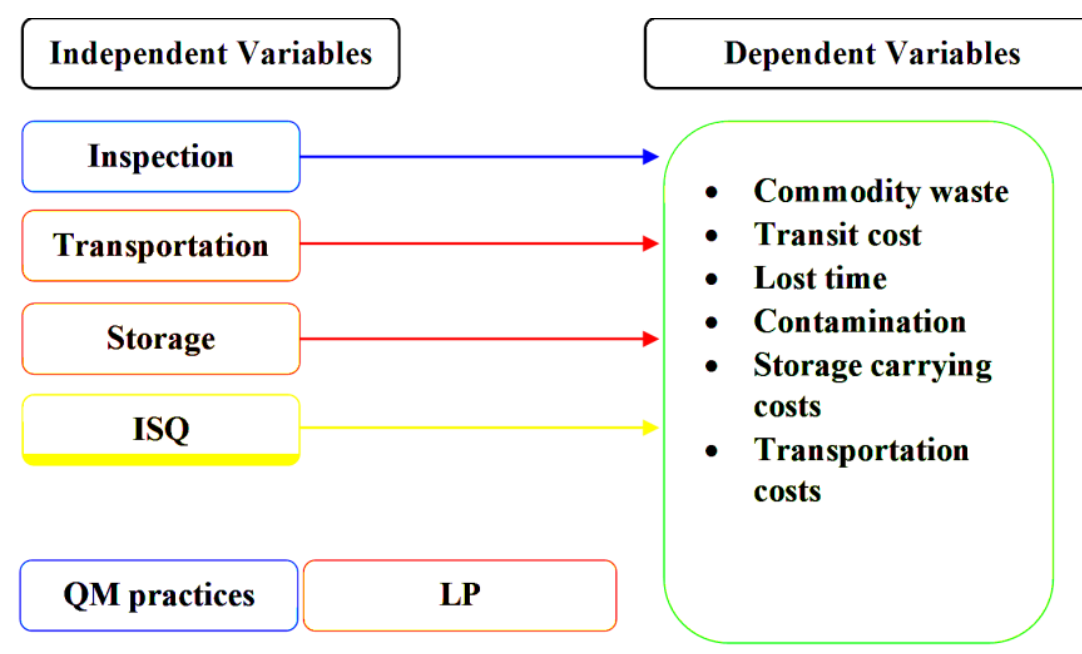

Figure 4: Applied Framework.

Source: Developed by the researcher 
It is worth mentioning that not all the elements within each of the practices proposed in the conceptual framework are applicable. In this context, it was found that quality management practices come on the top of the list in terms of importance to the decision makers, however, their reflection represented in the inspections processes was found to be one of the costliest. Transportation and storage are the reflection of lean practices category, this group represent the cornerstone of the wheat supply chain, the prevailing opinion among all interviewees and focus groups participants.

It should be noted that the scope of this research is limited only to Egypt, and due to the unique nature of the wheat sector, not all the supply chain participants are included in the study; only governmental organizations. Furthermore, the study gives more attention to the imported wheat as a result of its high associated supply chain costs. Moreover, the private sector participation in the supply chain operations is not within the scope of the study; since the aim of the research is to find actual solutions which are exclusively under the authority of governmental organizations.

The findings of this research should be cautiously addressed taking into consideration the limitations of the study. The first limitation is concerning the sample, which was selected on the basis of the relative authority and influence of organizations and agencies in the wheat supply chain in Egypt. The second limitation is regarding the results, which cannot be generalized as they are exclusive to the wheat sector in Egypt.

Both conceptual and applied frameworks are meant to address the subject of this research and within its scope; that is the Egyptian wheat supply chain, and cannot be generalized. However, same procedures can be applied to other sectors in order to formulate the adapted framework.

\section{5-Conclusion}

The research provides a thorough analysis on the wheat supply chain practices followed in Egypt; an area that has been overlooked by researchers over the past years, its contribution to the body of knowledge are represented in the following points: first, it managed to 
identify the supply chain practices that influence the wheat sector in Egypt. Second, it pointed out that inspection, transportation, and storage are the main areas of the supply chain facing problems. Third, it highlighted key problems in the configuration of supply chain, which are: (1) current data on supply chain practices and performance are neither reliable nor sufficient, (2) revealed performance indicators on activities and practices are very limited and for some practices inexistent, (3) the available structure and current data cannot build a reliable supply chain model that can predict changes or projections for future improvements.

The research also reached the conclusion that, not all the variables in the conceptual framework apply on the wheat supply chain in Egypt, either because there is a miscomprehension of a variable, or because it simply does not apply; the concept of sustainability and its pillars is perceived by the majority of organizations, only as the environmental impact of the accompanying practices within the supply chain; the applicability of the framework is subject to the degree to which organizations are willing to modify their operations, as well as the overall development strategy that encompasses all the organizations and entities within the wheat sector.

The findings of this research should be cautiously addressed taking into consideration the limitations of the study. The first limitation is concerning the sample, which was selected on the basis of the relative authority and influence of organizations and agencies in the wheat supply chain in Egypt. The second limitation is regarding the results, which cannot be generalized as they are exclusive to the wheat sector in Egypt. Both conceptual and applied frameworks are meant to address the subject of this research and within its scope; that is the Egyptian wheat supply chain, and cannot be generalized. However, same procedures can be applied to other sectors in order to formulate the adapted framework.

Future researches can investigate other aspects of the wheat supply chain such as the influence of private sector on performance, also the sourcing process of the local wheat which is underdeveloped and is a prospect research point, the effect of organizational structure on supply chain performance. 


\section{References}

Ahram Online. (2019). Egypt Buys 2.7 Mln Tonnes of Local Wheat So Far This Season. [online] Available at:

Al-Shboul, M.; Barber, K.; Garza-Reyes, J.; Kumar, V. and Abdi, M. (2017). The Effect of Supply Chain Management Practices on Supply Chain and Manufacturing Firms' Performance. Journal of Manufacturing Technology Management. 28(5), 577-609.

AL-Shboul, M.; Garza-Reyes, J. and Kumar, V. (2018). Best Supply Chain Management Practices and High-performance Firms. International Journal of Productivity and Performance Management, 67(9), 1482-1509.

Carter, C.; Rogers, D. and Choi, T. (2015). Toward the Theory of the Supply Chain. Journal of Supply Chain Management, 51(2), 89-97.

Duong, B.; Truong, H.; Sameiro, M.; Sampaio, P.; Fernandes, A.; Vilhena, E.; Bui, L. and Yadohisa, H. (2019). Supply Chain Management and Organizational Performance: The Resonant Influence. International Journal of Quality \& Reliability Management. 36(7), 1053-1077.

El-Sakty, K. and Ezzat, A., (2018). The Impact Study of Logistics System Efficiency of Wheat in Egypt. Arab Journal for Management, 38(1), 23-34.

Gandhi, A.; Shaikh, A. and Sheorey, P. (2017). Impact of Supply Chain Management Practices on Firm Performance. International Journal of Retail \& Distribution Management. 45(4), 366-384.

Gawankar, S.; Kamble, S. and Raut, R. (2017). An investigation of the relationship between supply chain management practices (SCMP) on supply chain performance measurement (SCPM) of Indian retail chain using SEM. Benchmarking: An International Journal, 24(1), 257-295. 
Gawankar, S.; Kamble, S. and Verma, R. (2013). Effect of Supply Chain Management Practices on Supply Chain Profitability: An Empirical Investigation Using Structural Equation Modelling in Indian Retail Sector. International Journal of Services and Operations Management. 16(2), 145.

Gorane, S. and Kant, R. (2017). Supply Chain Practices and Organizational Performance. The International Journal of Logistics Management. 28(1), 75-101.

Green, K.; Zelbst, P.; Meacham, J. and Bhadauria, V. (2012). Green Supply Chain Management Practices: Impact on Performance. Supply Chain Management: An International Journal. 17(3), 290-305.

http://english.ahram.org.eg/NewsContent/3/12/335251/Business/Ec onomy/Egypt-buys--mln-tonnes-of-local-wheat-so-far-this-.aspx

Ibrahim, H. (2015). Optimizing construction and utilization of wheat storage facilities to minimize post-harvest losses. Ph.D. University of Illinois.

Jabbour, A.; Filho, A.; Viana, A. and Jabbour, C. (2011). Measuring Supply Chain Management Practices. Measuring Business Excellence. 15(2), 18-31.

Karimi, E. and Rafiee, M. (2014). Analyzing the Impact of Supply Chain Management Practices on Organizational Performance through Competitive Priorities (Case Study: Iran Pumps Company). International Journal of Academic Research in Accounting, Finance and Management Sciences. 4(1).

Kumar, A. and Kushwaha, G. (2018). Supply Chain Management Practices and Operational Performance of Fair Price Shops in India: an Empirical Study. Scientific Journal of Logistics, 14(1), 85-99.

Laosirihongthong, T.; Adebanjo, D. and Choon Tan, K. (2013). Green Supply Chain Management Practices and Performance. Industrial Management \& Data Systems. 113(8), 1088-1109.

LeMay, S.; Helms, M.; Kimball, B. and McMahon, D. (2017). Supply chain management: the elusive concept and definition. The International Journal of Logistics Management, 28(4), 1425-1453. 
Li, Y. and Ye, H. (2014). How to Achieve a Strategic Sustainable Supply Chain Management (SSCM)? A Case Study of Swedish Global Enterprise. MSc. Högskolan I Gävle.

McGill, J.; Prikhodko, D.; Sterk, B.; Talks, P. (2015). Egypt Wheat Sector Review.

Mentzer, J.; DeWitt, W.; Keebler, J.; Min, S.; Nix, N.; Smith, C. and Zacharia, Z.; (2001).Defining Supply Chain Management. Journal of Business Logistics, 22(2), 1-25.

Mentzer, J.; Myers, M. and Stank, T. (2007). Handbook of Global Supply Chain Management. Thousand Oaks: Sage Publications.

Neama, A. (2016). Analytical Study of the Lost in Wheat Crop from Producer to the Final Consumer in Sharkia Governorate. Egyptian Journal for Agriculture Research. 94(1), 189-209.

Okongwu, U.; Brulhart, F. and Moncef, B. (2015). Causal Linkages Between Supply Chain Management Practices and Performance. Journal of Manufacturing Technology Management. 26(5), 678-702.

Roy, V.; Schoenherr, T. and Charan, P. (2018). The thematic landscape of literature in sustainable supply chain management (SSCM). International Journal of Operations and Production Management, 38(4), 1091-1124.

Sundram, V.; Chandran, V. and Bhatti, M. (2016), Supply Chain Practices and Performance: The Indirect Effects of Supply Chain Integration. Benchmarking: An International Journal. 23(6), 14451471.

Talib, F.; Rahman, Z. and Qureshi, M. (2011). A Study of Total Quality Management and Supply Chain Management Practices. International Journal of Productivity and Performance Management. 60(3), 268-288.

Truong, H.; Sameiro, M.; Fernandes, A.; Sampaio, P.; Duong, B.; Duong, H. and Vilhenac, E. (2017). Supply Chain Management Practices and Firms' Operational Performance. International Journal of Quality \& Reliability Management. 34(2), 176-193. 
Varsei, M.; Soosay, C.; Fahimnia, B. and Sarkis, J. (2014). Framing sustainability performance of supply chains with multidimensional indicators. Supply Chain Management: An International Journal, 19(3), 242-257.

W.A.D.S., W. (2013). The Role of Supply Chain Management Practices in Achieving Organizational Performance Through Competitive Advantage in Sri Lankan SMES. ISERD International Conference Singapore.

Wang, J. and Dai, J. (2018). Sustainable Supply Chain Management Practices and Performance. Industrial Management \& Data Systems. 118(1), 2-21.

Yildiz Çankaya, S. and Sezen, B. (2019). Effects of Green Supply Chain Management Practices on Sustainability Performance. Journal of Manufacturing Technology Management. 30(1), 98-121.

Younis, H.; Sundarakani, B. and Vel, P. (2016). The Impact of Implementing Green Supply Chain Management Practices on Corporate Performance. Competitiveness Review. 26(3), 216-245. 


\section{Appendix}

\section{Semi-structure Interviews}

\section{Title}

Developing a Sustainable Supply Chain Management Practices Framework: A Case Study on the Egyptian Wheat Sector.

\section{Purpose}

To evaluate and assess the current wheat supply chain practices compared to the proposed conceptual framework in order to reach realtime data on the situation of the supply chain and performance.

\section{Participants}

A number of experts and specialists from governmental organizations, agencies and academics with former background in the field. They are selected based on practical experience in the field, comprising representatives from the Ministry of Supply and Internal Trade, the General Authority for Supply Commodities, the Egyptian Holding Company for Silos and Storage, and academics with former participation in the Food and Agriculture Organization, and Food Industries Holding Company.

\section{Procedures}

Participants were reached though emails and phone calls, and interviews timings were set according to their convenience.

\section{Analysis}

Interview data were transcribed right after the interview was conducted, then results were coded and categorized thematically, with head questions being the main categorizing lead in this process, data was then labeled with total discretion to the identity of the interviewees. After sorting and labeling transcribed data is put in order, the software NVIVO was used - due to the large number of interviews conducted - to analyze the data. 


\section{Introduction}

Thank you for accepting the invitation. Our interview today is mainly concerned with grasping detailed information on the wheat supply chain practices and its performance in Egypt. The duration of the discussion is approximately one hour. Anything you say here will be kept confident.

\section{Questions}

- Describe the wheat supply chain in Egypt.

- From your point of view, what is the current situation of the wheat supply chain in Egypt with regards to modernism and performance?

- What are the major drawbacks in the wheat supply chain?

- What are the costliest practices in the wheat supply chain?

- What are the initiatives taken to enhance the current performance of the wheat supply chain in Egypt?

- To which extent is the wheat supply chain sustainable?

- Provided the given theoretical framework, what is the relative importance of each of the variables with respect to the current situation?

\section{Summary}

What I have heard you saying .........., did I summarize your words correctly? Is there anything you would like to add or amend?

Thank you for your precious time and participation. 


\section{إعداد إطار للإدارة المستدامة لأنشطة سلاسل الإمداد: دراسة حالة عن قطاع القمح} المصري

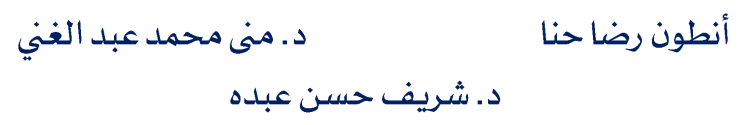

تضـم أنشـطة سـلاسـل الإمداد العلاقات الداخلية في المؤسـسـة، وتلك الخارجية التي تشـاركها مع شـركائها، وتدمجها بشـكل

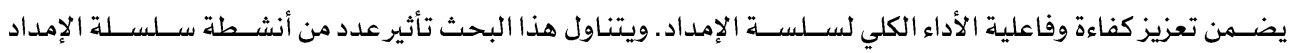

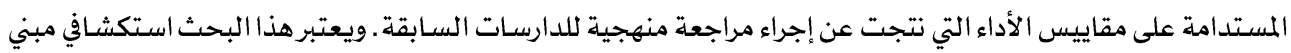

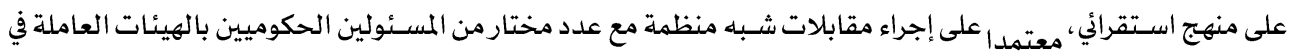

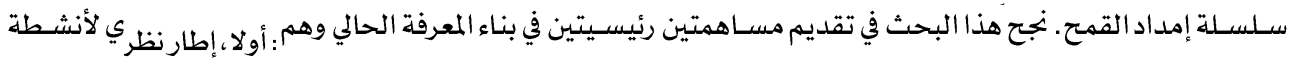

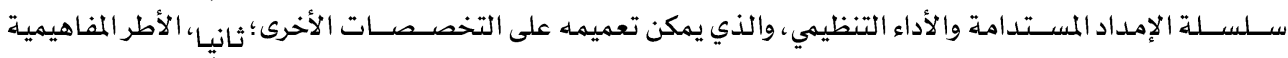

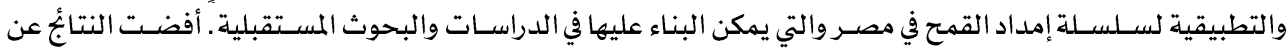

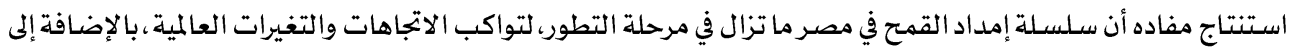
الاحتياجات المحلية؛ ومع ذلك، فهي ليست منظمة بشكل مستدام بعد. أما فيما يخص أنشطة سلسلة الإمداد الخاصة بها،

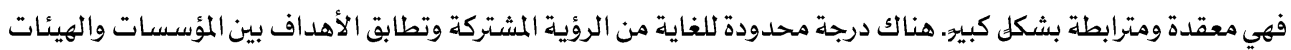

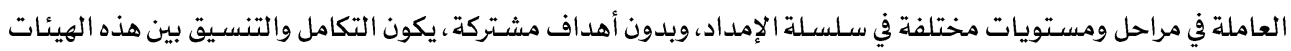

المعنية أمراٍ مستحيلا' الكلمات الدالة: إدارة سلاسل الإمداد، أنشطة وممارسات سلسلة الإمداد، الاستدامة، سلاسل الإمداد المستدامة.

\section{Suggested Citation according to APA Style}

Hanna, A. R.; AbdElghany, M. M. and Abdou, S. H. (2021). Developing a Sustainable Supply Chain Management Practices Framework: A Case Study on the Egyptian Wheat Sector. Journal of Alexandria University for Administrative Sciences, Faculty of Commerce, Alexandria University 58(2), 243 - 259. 


\section{مجلة جامعتة الإسكندـريـة للعلوم الإداريـة متاحة على : بوابة بنك المعرفة المصري}

\section{Egyptian Knowledge Bank (EKB)}

\section{https://acjalexu.journals.ekb.eg/}

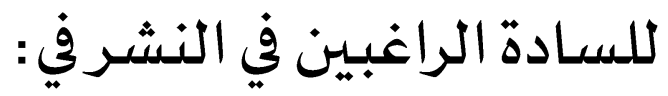

\section{مجلة جامعة الإسكندرية للعلوم الإدارية (مجلة كلية التجارة للبحوث العلمية سابقا)}
يمكن إرسال الأبحاث على البريد الإلكتروني الرسمي للمجلة

\section{JAS.AU@alexu.edu.eg}

$$
\text { تقييم المجلة في لجان الترقية } 6.5 \text { درجة }
$$

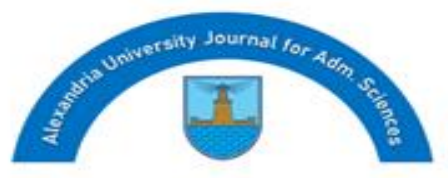

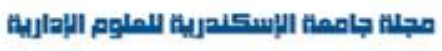

AUJAS

3) Sinoe 1953

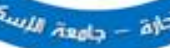

